\title{
Comparison of laboratory findings in PCR-positive and IgM-positive Crimean-Congo hemorrhagic fever cases
}

\section{PCR-pozitif ve IgM-pozitif Kırım-Kongo kanamalı ateși olgularında laboratuvar bulgularının karșılaștırılması}

\section{Yasemin COȘGUN ${ }^{1}$ (ID), Dilek MENEMENLIOĞLU² (ID), Ahmet SAFRAN³ (ID), Burcu GÜRER GiRAY ${ }^{4}$ (ID), Esma ÖDEVLi ${ }^{5}$ (ID), Seda GÜDÜL HAVUZ ${ }^{6}$ (ID), Erkan ÖZMEN ${ }^{7}$ (ID), Ali Korhan SIĞ ${ }^{8}$ (ID), Ahmet AYDEMiR ${ }^{1}$ (ID), Dilek YAĞCI ÇAĞLAYIK ${ }^{9}$ (ID), Gülay KORUKLUOĞLU1 (ID), Seher TOPLUOĞLU³ (ID), Selçuk KILIÇ ${ }^{10}$ (ID)}

\section{ABSTRACT}

Objective: Crimean-Congo hemorrhagic fever (CCHF) develops in one-fifth of the individuals infected with the CCHF virus. The clinical course progresses very rapidly and can result in death within 7-10 days. The aim of this study is to determine whether there is a difference between the PCR-positive period and the IgM-positive period in terms of laboratory findings and to investigate the effect of the difference, if any, on the course of the disease.

Methods: Results of 5131 serum samples submitted to public health laboratories for the diagnosis of $\mathrm{CCHF}$ between January 1, 2015, and December 31, 2017, were included in the study. PCR and IFA IgM test results of these samples and other laboratory findings of the patients were evaluated. Findings were compared between fatal and non-fatal cases.

Results: When laboratory results of the PCRpositive period and IgM-positive period were compared, there was a statistically significant difference in terms

\section{ÖZET}

Amaç: Kırım-Kongo kanamalı ateși (KKKA) hastalığı, KKKA virüsü ile enfekte bireylerin bește birinde meydana gelir. Hastalı̆ı̆n klinik seyri çok hızlı ilerleyerek 7-10 gün içinde ölümle sonuçlanabilmektedir. Bu çalıșmanın amacı, laboratuvar bulguları açısından PCR-pozitif dönem ile IgM-pozitif dönem arasında fark olup olmadığını belirlemek, varsa farklılığın hastalığın seyrine etkisini araștırmaktır.

Yöntem: 1 Ocak 2015 - 31 Aralık2017 tarihleri arasında KKKA tanısı amacıyla halk sağlığı laboratuvarlarına gönderilen 5131 serum örneği çalıșmaya dahil edildi. Bu örneklerin PCR ve IFA-IgM testi sonuçları ve hastaların diğer laboratuvar bulguları değerlendirildi. Yașamını sürdüren ve ölümcül seyreden hastaların bulguları karșılaștırıldı.

Bulgular: PCR-pozitif dönem ve lgM-pozitif döneme ait laboratuvar sonuçları karșılaștırıldığında, kreatinin değeri, trombositopeni varlığı $(<150.000), 20.000$ 'in

'Republic of Turkey, Ministry of Health, Public Health General Directorate, Microbiology Reference Laboratories and Biological Products Department, National Virology Reference Laboratory

${ }^{2}$ Hacettepe University Vaccine Institute

${ }^{3}$ Republic of Turkey, Ministry of Health, Public Health General Directorate, Zoonotic and Vector Borne Diseases Department

${ }^{4}$ Republic of Turkey, Ministry of Health, Ankara Provincial Health Directorate, Public Health Laboratory

${ }^{5}$ Republic of Turkey, Ministry of Health, Istanbul Provincial Health Directorate, Public Health Laboratory

${ }^{6}$ Republic of Turkey, Ministry of Health, Samsun Provincial Health Directorate, Bafra State Hospital

${ }^{7}$ İzmir Katip Celebi University, Ataturk Training and Research Hospital

${ }^{8}$ Republic of Turkey, Ministry of Health, Balikesir Provincial Health Directorate, Ataturk State Hospital

${ }^{9}$ Marmara University, Pendik Training and Research Hospital

${ }^{10}$ University of Health Sciences, Gulhane Institute of Defensive Health Sciences

İletişim / Corresponding Author : Yasemin COŞGUN

DOI ID : 10.5505/TurkHijyen.2021.77854

Coșgun Y, Menemenlioğlu D, Safran A, Gürer Giray B, Ödevli E, Güdül Havuz S, Özmen E, Sığ AK, Aydemir A, Yağcı Çağlayık D, Korukluoğlu G, Topluoğlu S, Kılıç S. Comparison of laboratory findings in PCR-positive and IgM-positive Crimean-Congo hemorrhagic fever cases. Turk Hij Den Biyol Derg, 2021; 78(4): 401 - 410 
of creatinine value, presence of thrombocytopenia $(<150,000)$, platelet count below 20,000, and creatine kinase (CK), lactate dehydrogenase (LDH) and international normalized ratio (INR) levels $(p<0.05)$. In the PCR-positive period, all of these findings were observed to increase detrimentally for the patient. In fatal cases; Presence of thrombocytopenia, platelet count of $\leq 20,000 / \mu \mathrm{L},>2.5 \mathrm{mg} / \mathrm{dL}$ creatinine level, and CK, LDH and INR values were found to be significantly higher $(\mathrm{p}<0.05)$.

Conclusion: In our study, the PCR-positive period, or the period in which viremia continues, was found to be a critical period in which all findings deteriorated for the patients. Furthermore, the presence of thrombocytopenia with platelet levels below 20,000/ $\mu \mathrm{L}$ was the most common mortality-related finding $(p<0.001)$. CK, LDH, and INR elevations were determined as other findings related to mortality. We believe these results will assist clinicians in predicting the prognosis and clinical management of the disease.

Key Words: CCHF, thrombocytopenia, fatality altında trombosit sayısı, kreatin kinaz (CK), laktat dehidrojenaz (LDH) ve uluslararası normalleştirilmiş oran (INR) seviyeleri açısından istatistiksel olarak anlamlı fark bulunmuștur $(p<0.05)$. PCR-pozitif dönemde tüm bu bulguların hasta açısından olumsuz yönde arttığı görüldü. Ölümcül seyreden olgularda; trombositopeni varlığı, $\leq 20.000 / \mu \mathrm{L}$ trombosit sayısı, >2.5 mg / dL kreatinin düzeyi, ve CK, LDH ve INR değerleri anlamlı düzeyde daha yüksek bulundu $(p<0.05)$.

Sonuç: Çalışmamızda PCR-pozitif dönem veya vireminin devam ettiği dönem hastalar için tüm bulguların kötüleștiği kritik bir dönem olarak bulundu. Ayrıca, $20.000 / \mu$ L'nin altında olan trombositopeni varlığı, ölümle ilișkili en sık bulguydu $(p<0.001)$. Mortalite ile ilgili diğer bulgular CK, LDH ve INR yükselmeleri olarak belirlendi. Bu sonuçların, hastalığın prognozunun tahmin edilmesi ve klinik yönetiminde klinisyenlere yardımcı olacağına inanıyoruz.

Anahtar Kelimeler: KKKA, trombositopeni, ölüm

\section{INTRODUCTION}

Crimean-Congo hemorrhagic fever (CCHF) is a zoonotic disease caused by the CCHF virus, which is a segmented, single-stranded, negative-polarized, enveloped RNA virus of the genus Nairovirus, belonging to the family Bunyaviridae, found in the arbovirus group. Transmission is caused by saliva and feces that the tick releases during bloodsucking $(1,2)$. Symptoms of CCHF disease in humans are very severe, and the clinical picture develops in one-fifth of the individuals infected with the virus; the clinical course progresses very rapidly and can result in death within 7-10 days $(1,3)$. Confirmed cases of CCHF were diagnosed for the first time in Turkey in 2002, and the disease still continues to be a public health problem in some areas of the country; since 2002, a total of 10,543 cases were reported (4). Despite the increase in the number of annual cases until 2009, in the following years, the number of cases gradually decreased due to the continuous education of the public and health workers, the awareness of the public about the disease, tick control by application of acaricides to livestock, the timely and correct treatment approaches of experienced physicians, and other unknown reasons (4). Furthermore, it is seen that the case fatality rate in Turkey, which is around $5 \%$, is much lower than the rates reported from other countries in which CCHF cases are found (4). The prognosis is worse in patients with hemorrhagic 
findings $(5,6)$.

There are four different periods of CCHF infection: the incubation, prehemorrhagic, hemorrhagic, and recovery periods. The incubation period is usually 1-3 days if the infection occurred with a tick bite; however, it may take up to 9 days. If the contamination is caused by contaminated blood, body fluids, tissues, or waste, this period lasts 5-6 days and can even last up to 13 days. The prehemorrhagic period lasts about 3 days (1-7 days). During this period, symptoms such as fever, headache, fatigue, joint and muscle pain, abdominal pain, nausea, vomiting, diarrhea, sore throat, and jaundice are seen. The disease is most commonly seen as petechiae-purpura in the hemorrhagic period. Epistaxis, hemoptysis, melena and hematuria are common clinical symptoms. It usually takes 2-3 days. In severe cases, diffuse intravascular coagulation, shock, nervous system dysfunction, coma, liver failure, kidney failure, and respiratory failure may develop. Death usually occurs between the 5th and 14th days of the disease $(6,7)$. The recovery period begins within 10-20 days after the onset of the disease $(1,2,6-8)$. Thrombocytopenia is a laboratory finding that is always seen in cases of CCHF disease. Elevation of alkaline phosphatase (ALP), gamma-glutamyltransferase (GGT), and LDH levels are followed by elevated levels of aspartate aminotransferase (AST), alanine aminotransferase (ALT), CK, and bilirubin (3-5). Significant deterioration occurs in prothrombin time, activated partial thromboplastin time, and other clotting tests. (4-6). In non-fatal cases the laboratory findings, including complete blood counts and biochemical tests, usually, reach normal levels within 5-9 days (6-8). CCHF should be considered in cases of symptoms such as fever, myalgia, bleeding, tick bite history, residence in endemic areas or travel to these areas, suspected contact history, exposure to known viruses, platelet counts of $<150,000 / \mathrm{mm} 3$, and leukopenia $(4,9)$. Some researchers have proposed some criteria in order to develop severity scoring systems to predict the prognosis and mortality of the disease (10-12).
These criteria consist of demographic, clinical and laboratory findings and constitute scores such as severity grading score (SGS) system and severity scoring index (SSI) that try to predict prognosis $(11,12)$. Molecular and serological tests are used for laboratory diagnosis in CCHF. PCR positivity in clinical specimens, $\mathrm{CCHF}$ virus IgM positivity in serum samples or fourfold increase in specific lgG positivity are accepted as laboratory-positive (13-14). However, in severe cases, antibody response may not be detected $(5,15)$. PCR is positive in the first 9-day period, and $\lg \mathrm{M}$ is positive in the period between 7 days and four months after the onset of the disease $(5,13,16)$. Clinically, the period of viremia and PCR positivity corresponds to the incubation, prehemorrhagic, and hemorrhagic periods, while the detection of IgM starts in the hemorrhagic period and continues for several months. IgG antibodies can also be found in serum at about days 7-10 of the disease and can be detected for up to five years (16). The aim of this study is to determine whether there is a significant difference between the PCR-positive period and IgMpositive period of CCHF in terms of disease findings and to investigate the effect of this difference in determining the prognosis of the disease.

\section{MATERIAL and METHOD}

Results of serum samples submitted to our public health laboratories for the diagnosis of CCHF between January 1, 2015, and December 31, 2017, were included in this study. A total of 5131 samples, 3317 of which were PCR and IgM negative, were included in the study. According to the laboratory algorithm, a sample sent to the laboratory for the first time from a patient is firstly PCR tested, reported if positive, and IgM test is not applied because it is diagnosed. If the expected second sample is sent at least 10 days after the same patient, only IgM test is applied, PCR test is not applied. Because now it is the time period where PCR becomes negative and IgM formation is expected. If the PCR test is found to be negative in 
the first sample, the IgM test is definitely applied and if the IgM is positive, it means that the viremia period has passed and the antibody has started to form. The extract from each sample was tested using a real-time PCR kit (Altona, Hamburg, Germany) and its system (Rotor-Gene, Qiagen) for the presence of the CCHF virus. The IIFT CCHFV Mozaic 2 commercial kit (Euroimmun, Lübeck, Germany) was used for the CCHF virus IgM assay, and the results were examined under fluorescence microscopy. In addition to laboratory findings such as thrombocytopenia, platelet count, INR, and creatinine, CK, and LDH levels, demographic and anamnesis findings such as age, sex, and history of tick bite, or tick contact were also examined. Creatinine level was accepted as a criterion for renal failure at $2.5 \mathrm{mg} / \mathrm{dL}$ and above (17). Findings were compared according to PCR and IFA IgM positivity. Findings of non-fatal and fatal cases were also compared. The data were obtained from patient and laboratory information systems and laboratory book records and organized as an excell file.

\section{Statistical analysis}

Non-parametric data were expressed as medians and min-max, categorical data as percentages. Student's t-test was used to compare continuous variables and Chi-square test was used for categorical variables. Proportions for categorical variables were compared using the chi square test. A value of $p<0.05$ was considered significant in all analyses. The data were analyzed using SPSS 15.0 (SPSS Inc., Chicago, IL, USA).

This study was approved by the Ankara City Hospital Ethics Committee Number 2 (Date: 01.09.2021 and Number: E. Kurul - E2-21-770).

\section{RESULTS}

The average age of the patients was determined as 46.4 years. Considering the distribution by gender, $59.1 \%$ (882) of the patients were male and $40.9 \%$ (610) were female. Median age (min-max) was 49 (0-90) for females and 49 (0-84) for males and were similar.

Of the 5131 sera sent with CCHF prediagnosis, 1296 were positive for CCHF virus by PCR, 518 were positive for IFA IgM, and 3317 were negative for both PCR and IFA IgM. IFA IgM positivity was detected in the second samples sent to the laboratory from 321 PCRpositive patients. In only 197 of 1493 CCHF cases, the first samples were PCR-negative and IgM-positive (Table 1).

PCR-positive results, PCR-negative/lgM-positive results, and PCR-negative/lgM-negative results were

Table 1. Classification of patient and sample numbers according to PCR and IgM test results

\begin{tabular}{|c|c|c|c|}
\hline Characteristics of the patients and sample groups & $\begin{array}{l}\text { Number of cases or } \\
\text { samples }\end{array}$ & $\begin{array}{l}\text { Total number of } \\
\text { cases }\end{array}$ & $\begin{array}{l}\text { Total number of } \\
\text { samples }\end{array}$ \\
\hline $\begin{array}{l}\text { Patient group with PCR positive results and the first } \\
\text { sample received }\end{array}$ & 1296 & \multirow{2}{*}{$\begin{array}{c}\text { Total number } \\
\text { of laboratory } \\
\text { confirmed cases: } \\
1493\end{array}$} & \multirow{4}{*}{$\begin{array}{l}\text { Total number of } \\
\text { samples: } 5131\end{array}$} \\
\hline $\begin{array}{l}\text { Patient group with PCR negative -IgM positive results } \\
\text { and only one sample }\end{array}$ & 197 & & \\
\hline $\begin{array}{l}\text { Patient group with PCR negative -IgM negative results } \\
\text { and only one sample }\end{array}$ & 3317 & & \\
\hline $\begin{array}{l}\text { Patient group whose } 2 \text { samples came } 10 \text { days apart } \\
\text { and the first sample was PCR positive and the second } \\
\text { sample was IgM positive }\end{array}$ & 321 & & \\
\hline Total number of IgM positive samples & $518(197+321)$ & & \\
\hline
\end{tabular}


evaluated with other anamnesis and laboratory findings of the patients. When the laboratory results are compared, in the PCR positive group; creatinine value, presence of thrombocytopenia $(<150,000)$, rate of platelet count below 20.000 and CK, LDH and INR levels were significantly higher than IgM positive group ( $\mathrm{p}$ 0.05). In the PCR-positive cases, all of these findings were elavated unfavorably for the patient. There was no statistically significant difference between the two groups in terms of tick bite history ( $p$ $=0.2187$ ). When laboratory results of the patients with fatal and non-fatal cases were compared, significant differences were found between creatinine level, presence of thrombocytopenia, thrombocyte levels of $20.000 / \mu \mathrm{L}$ and less, and high CK, LDH and INR (p $<0.05$ ) (Figure 1). In patients with PCR-negative/lgMnegative CCHF tests, the creatinine level was found to be significantly higher than in the CCHF-positive (PCR or IgM) group. In the negative group, the presence of thrombocytopenia, high INR, CK, and LDH levels was also quite common. When our study was evaluated in terms of tick biting history; There was no significant difference between PCR-positive and PCR-negative / IgM-positive cases. Tick bite history was $59 \%$ in the PCR positive group, while $56 \%$ in the IgM positive group. Approximately $40 \%$ of the PCR and IgM negative patient group had a history of tick bite. The mortality rate was $4.1 \%(61 / 149)$ for the average of three years. All laboratory findings of the patients were higher in deceased patients, than that in nonfatal cases ( $p$ 0.05). While PCR positivity was more prominent than IgM in fatal cases ( $p$ is <.00001), it was observed that IgM positivity was predominant in non-fatal ones ( $p$ is <.00001). However, history of tick bite was significantly more common in the latter group $(p=0.0007)$ (Figure 2$)$.

\section{DISCUSSION and CONCLUSION}

Since CCHF is a disease with a variable clinical severity, determining some criteria in order to predict the prognosis of the disease can guide the clinician $(5,6)$. There are some studies in this field on various

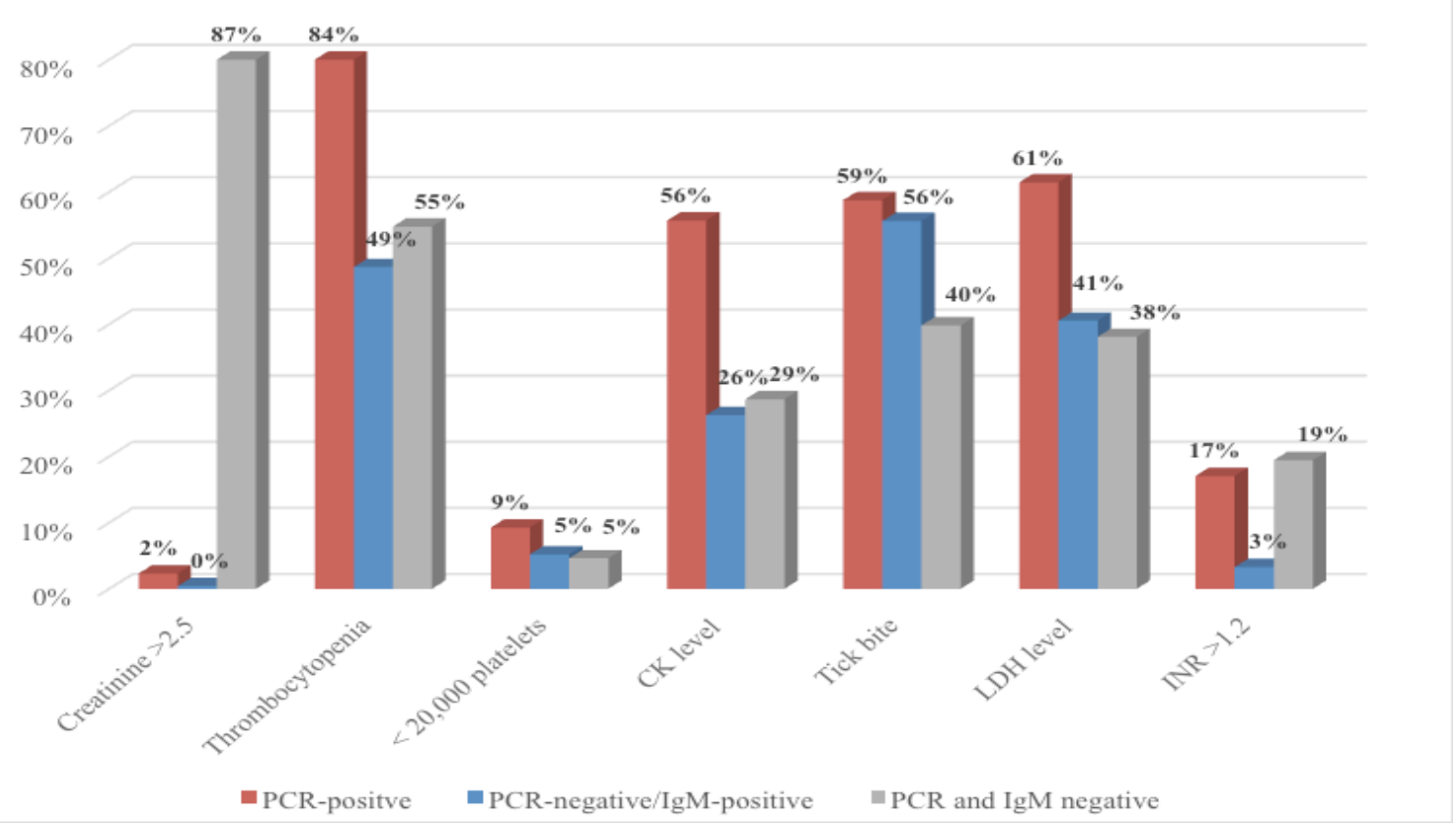

Figure 1. Laboratory findings of confirmed cases 


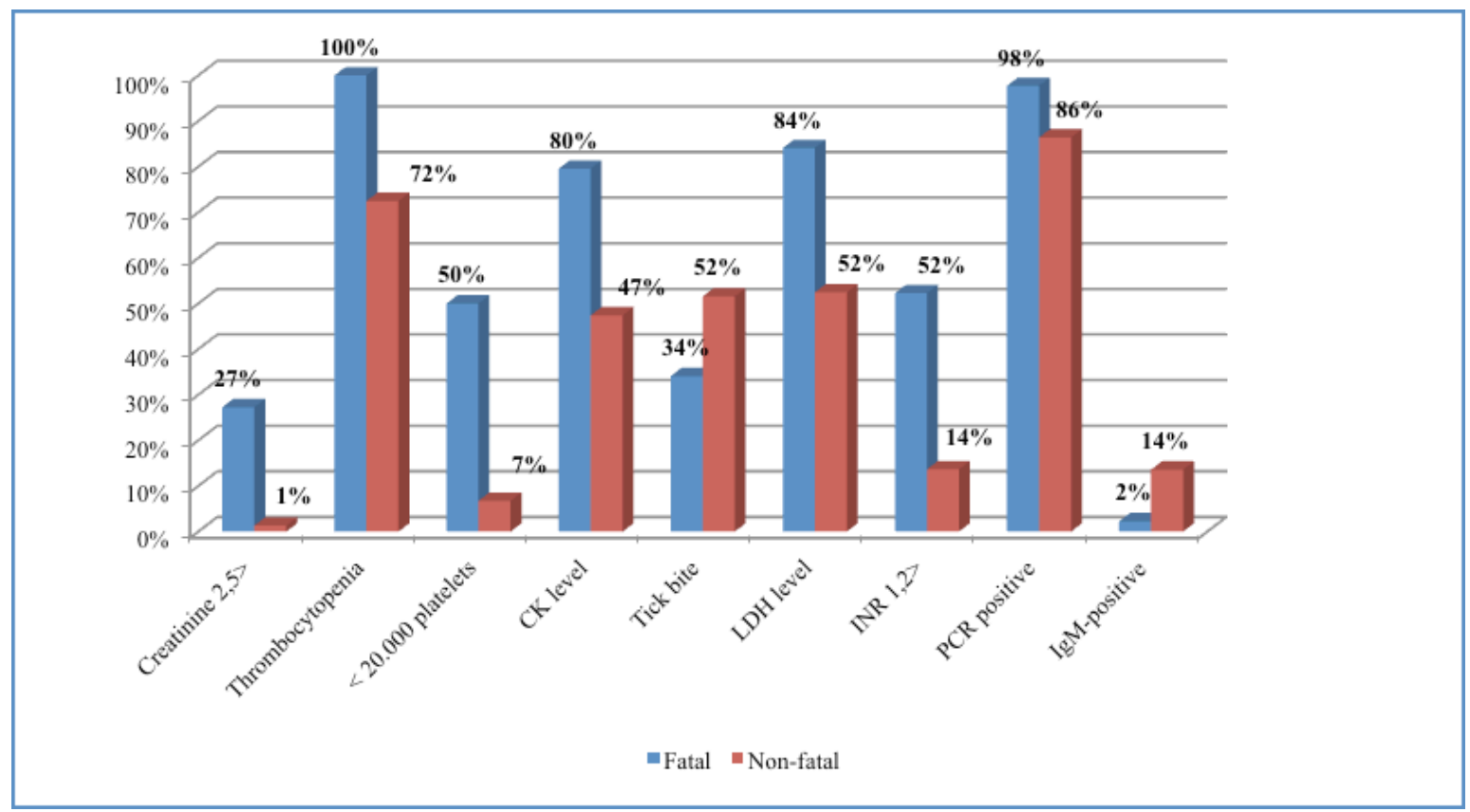

Figure 2. Laboratory findings of fatal and non-fatal cases

patient groups (10-12). In our study, 59.1\% of the patients were male and $40.9 \%$ were female. Similarly, Sumer et al. (18) reported that $51.8 \%$ of CCHF patients were male, and $48.2 \%$ were female. Also, in a study by Bilgin et al. (19), 51.6\% of patients were male and $48.4 \%$ were female. Thus, in consistent with other studies carried out in Turkey, a higher disease incidence was determined in men $(18,19)$. This may be due to the fact that men are more likely to visit areas inhabited by ticks than women.

The average age of the patients inluded in our study was 46.4 years, which remained unchanged across the three years of our study. This age group might have been engaged in agriculture and livestock. Alternatively, the symptoms might be more apparent in this age group. Accordingly, average age of the patient group that required hospitalization was reported to be between 40 and 50 years, in previous studies $(8,11,20)$.

In our study, 87\% of 1493 cases determined in a 3-year period were diagnosed with the PCR test, $13 \%$ of them were found to be negative for the PCR test and were diagnosed with IgM test positivity. This shows that serological tests must also be evaluated in cases that are found negative by PCR. This may be due to many reasons such as the late admission of patients with milder clinical findings to the hospital, overcoming the viremia period, the short duration of the viremia period, and the development of rapid antibody response.

When the laboratory findings of the PCR-positive and IgM-positive cases were compared; creatinine elevation, thrombocytopenia, platelet count below $20,000 / \mu \mathrm{L}$, and CK, LDH, and INR elevations were significantly more prevalent in the PCR-positive cases. These findings show that laboratory findings or vital functions worsen during the viremia period. From another point of view, showing that these findings are progressing in a bad direction shows that the virus is still not cleared from the body and continues to damage. When these are coupled with endothelial damage, coagulation disorders, or organ failure during viremia, it is vital that the patient be diagnosed early by PCR testing and provided with 
appropriate treatment $(10,19,26)$.

In the IgM positive period, the fact that the laboratory findings are significantly better indicates that the patient started to recover with the immune response produced against the virus, and in fact, IgM positivity may be a good indicator. While PCR positivity was more prominent than $\lg M$ in fatal cases, IgM positivity was found to be predominant in non-fatal cases. Antibody development can be considered as a sign of good prognosis, the risk of death is higher as long as viremia continues and PCR positivity is seen. In some patients, an antibody response does not develop and, viremia continues, leading to cases which are usually very severe or fatal. Kaya et al. (5) reported that there was a correlation between fatalities and the absence of IgG production; while the serum antiCCHF virus IgG levels in non-fatal cases increased rapidly during the monitoring period, insufficient IgG levels were seen in fatal cases. In patients with PCRnegative/lgM-negative CCHF tests, the creatinine level was found to be significantly higher than in the CCHF-positive (PCR or IgM) group. In the negative group, the presence of thrombocytopenia, high INR, CK, and LDH levels was also quite common. The high incidence of these findings in the negative group indicates that clinicians were aware of CCHF in the presence of these findings and sent samples to the laboratories.

When our study was evaluated in terms of tick biting history; There was no significant difference between PCR-positive and PCR-negative / IgMpositive cases. Tick bite history was $59 \%$ in the PCR positive group, while $56 \%$ in the IgM positive group. In other words, about $60 \%$ of the cases accepted as CCHF cases had a history of tick bite, and $40 \%$ did not. Even if there is no history of tick bite, it has been possible to detect these cases by sending samples to the laboratory from patients with findings suggestive of CCHF. In the studies, it has been reported that there is a history of tick bites in $55 \%$ to $65 \%$ of the cases. In our study, $57.9 \%$ of the patients with positive
CCHF tests had a history of tick bite. Similarly, Bilgin et al. (19), Hasanoglu et al. (20), Kaya et al. (5), and Copper et al. (6) reported it as 57.8\%, 62.6\%, 64.5\% and $60 \%$, respectively.

Interestingly, $40 \%$ of the CCHF PCR and IgM negative patient group had a history of tick bite. In this group of patients, despite the history of tick bite and presence of CCHF-like clinical and laboratory findings, there may be various reasons for not detecting positivity in the laboratory. If the patient is still considered to be a clinical case of CCHF, a new sample may need to be sent. Factors such as sampling time, suitable sample, appropriate sample transfer conditions, sensitivity of the test kit should be examined. If CCHF disease is excluded after laboratory results in the group with tick bite history, it should be kept in mind that other tick-borne viral or bacterial agents should also be investigated. On the other hand, in cases without tick bite history there may be various reasons such as contact with animals with ticks, contact with CCHF cases, separation of the tick after sucking blood and swelling, and the patient not being aware of this.

In studies in Turkey, mortality rates were calculated to be about $5 \%(4,14,21)$, whereas this rate is much higher in other countries reporting cases of CCHF $(15,22)$. In our study, the average three-year mortality rate among CCHF cases was calculated as $4.13 \%(61 / 1492)$, which is similar to the average mortality rate in our country $(4,21)$. The reason why the mortality rates due to CCHF disease in Turkey are lower than in other countries, can be explained by factors such as the strong surveillance system maintained in our country, the experience of physicians in the regions where the disease is endemic, prevention from the disease, early diagnosis and treatment thanks to strong training strategies $(4,14,21)$.

When the laboratory findings of fatal and nonfatal cases are compared, creatinine elevation (>2.5), the presence of thrombocytopenia, platelet count below $20,000 / \mu \mathrm{L}$, and elevated $\mathrm{CK}, \mathrm{LDH}$, and INR 
levels were found to be significantly more common in fatal cases than non-fatal cases. Some studies have reported that these and additional findings can be used to predict fatal or poor prognosis $(5,10-12,23$ 27). Tasdelen et al. reported that, advanced age, late admission, low platelet count, prolonged PT anda PTT values, and elevated AST, ALT, CK, and LDH levels might be early indicators of poor prognosis in patients with CCHF (25). Kazancioğlu et al. reported that elevated urea and aPTT levels were associated with mortality in CCHF patients (28). Mardani et al. found no difference in hemoglobin, platelet, AST, and GGT levels and erythrocyte sedimentation rates between the fatal and non-fatal cases. However, they reported that leukocyte counts were significantly lower and ALT, ALP, LDH, CK, and C-reactive protein levels were significantly higher in the fatal cases (9). Swanepoel et al. reported that in the early stages of the disease, if platelet counts are lower than 20 $\times$ 109/L, AST levels are above $200 \mathrm{U} / \mathrm{L}$, ALT levels are above $50 \mathrm{U} / \mathrm{L}$, aPTT is 60 seconds or more, or fibrinogen is $110 \mathrm{mg} / \mathrm{dL}$ or lower, the risk of mortality is above $90 \%$ (10). Hasanoglu et al. reported that the probability of survival in patients with AST of $>1130$ $\mathrm{U} / \mathrm{L}, \mathrm{ALT}$ of $>490 \mathrm{U} / \mathrm{L}, \mathrm{CK}$ of $>505 \mathrm{U} / \mathrm{L}$, LDH of $>980$ $\mathrm{U} / \mathrm{L}$, platelet count of $<23,000$, and creatinine of $>1.4$ was significantly reduced (20).

In summary, in our study, creatinine level of $>2.5$ and CK, LDH, and INR elevations were significantly more common in fatal cases compared to non-fatal cases. Thrombocytopenia was found in $84 \%$ of the non-fatal cases and all of the fatal cases. Platelet counts of $20,000 / \mathrm{mm} 3$ or less were present in $50 \%$ of the fatal cases, but only $8 \%$ of the non-fatal cases had platelet counts below 20,000. A history of tick bite was statistically significantly more common in non-fatal cases. It is an interesting finding that the presence of tick bites in deceased patients was lower than the rate seen in non-fatal cases. It is thought that deceased patients might not have noticed the tick bite, or there was no tick bite history and they contracted the virus due to direct contact with the body fluids of animals that were carrying the virus. This may lead to a more lethal outcome as these patients might have presented to the hospital later, creating a delay in their treatment. In patients with a history of tick bite, it was thought that the probability of survival increased due to reasons such as early removal of the tick, exposure to less virus load, and earlier treatment.

The limitations of our study include the inability to examine findings such as AST, ALT increase, PTaPTT prolongation in CCHF disease, the absence of IgM results in the first samples with PCR positivity, PCR and lgG test not performed on second samples and the analyzed data covering only a three-year period.

In conclusion, in our study, the PCR-positive cases displayed elevated levels of creatinine value, presence of thrombocytopenia $(<150,000)$, platelet count below 20,000, and CK, LDH, and INR levels than PCR-negative/IgM-positive. Furthermore, the presence of thrombocytopenia, particularly with platelet levels below 20,000, was the finding most associated with mortality. CK, LDH, and INR elevations were determined as other parameters related to mortality. It is beneficial to use PCR and serological tests together in the laboratory diagnosis of CCHF. Indication of antibody formation by the evaluation of a second set of samples in CCHF cases in 10 days after PCR positivity is detected may be an indicator for the good prognosis of the patient as well as for the confirmation of the laboratory diagnosis. The fact that the patient was in the PCR positive period, did not develop antibodies, and the platelet count was below 20,000 were the most important risk factors in terms of fatality. Interestingly, the presence of a history of tick bite was among the criteria for good prognosis. Clinical parameters are important as indicators to predict the prognosis of the patient and the probability of death. Since laboratory findings provide quantitative and objective data, it is much more beneficial to develop and use severity scoring systems using these parameters. We believe that 
our results will assist clinicians in case management, such as in commenting on the prognosis of the disease, administering supportive care, starting or interrupting ribavirin therapy, admitting the patient to the intensive care unit, or referring the patient to a better equipped hospital.

\section{ACKNOWLEDGMENT}

We want to thank all the physicians, assistant health personnel, and laboratory staff involved in the management of these CCHF patients.

\section{ETHICS COMITTEE APPROVAL}

* The study was approved by the Ankara City Hospital Ethics Committee Number 2 (Date: : 01.09.2021 and Number: E. Kurul - E2-21-770).

\section{CONFLICT OF INTEREST}

The authors declare no conflict of interest.

\section{REFERENCES}

1. Ergönül O. Crimean-Congo haemorrhagic fever. Lancet Infect Dis. 2006;6:203-14.

2. Akın L. Kırım-Kongo kanamalı ateși. Hacettepe Tıp Dergisi 2008;39:134-43.

3. Ergönül Ö. Kırım-Kongo kanamalı ateși. ANKEM Derg 2009;23:234-40.

4. https://hsgm.saglik.gov.tr/tr/zoonotikvektorelkkka (Accessed 08.09.2019).

5. Kaya S, Elaldi N, Kubar A, Gursoy N, Yilmaz M, Karakus G, et al. Sequential determination of serum viral titers, virus-specific IgG antibodies, and TNF-a, IL-6, IL-10, and IFN- $\gamma$ levels in patients with Crimean-Congo hemorrhagic fever. BMC Infect Dis. 2014;28:14:416.
6. Bakir M, Ugurlu M, Dokuzoguz B, Bodur H, Tasyaran MA, Vahaboglu H. Turkish CCHF Study Group. Crimean-Congo haemorrhagic fever outbreak in Middle Anatolia: a multicentre study of clinical features and outcome measures. J Med Microbiol. 2005;54:385-9.

7. Cevik MA. Kırım-Kongo hemorajik ateși: klinik özellikler. KLiMiK Derg 2004;17:59-61.

8. Karti SS, Odabasi Z, Korten V, Yilmaz M, Sonmez M, Caylan R, et al. Crimean-Congo Hemorrhagic Fever in Turkey. Emerg Infect Dis. 2004;10;1379-84.

9. Mardani M, Jahromi MK, Naieni KH, Zeinali $M$. The efficacy of oral ribavirin in the treatment of crimean-congo hemorrhagic fever in Iran. Clin Infect Dis. 2003;36:1613-8. 
10. Swanepoel R, Gill DE, Shepherd AJ, Leman PA, Mynhardt JH, Harvey S. The clinical pathology of Crimean-Congo hemorrhagic fever. Rev Infect Dis. 1989;11:794-800.

11. Bakir M, Gozel MG, Koksal I, Asik Z, Gunal O, Yılmaz $\mathrm{H}$, et al. Validation of a severity grading score (SGS) system for predicting the course of disease and mortality in patients with Crimean-Congo hemorrhagic fever (CCHF). Eur J Clin Microbiol Infect Dis. 2015;34:325-30.

12. Dokuzoguz B, Celikbas AK, Gök ȘE, Baykam N, Eroglu MN, Ergönül Ö. Severity Scoring Index for Crimean-Congo Hemorrhagic Fever and the Impact of Ribavirin and Corticosteroids on Fatality. Clin Infect Dis. 2013;57:1270-4.

13. Chinikar S, Goya MM, Shirzadi MR, Ghiasi SM, Mirahmadi R, Haeri A, et al. Surveillance and laboratory detection system of Crimean-Congo haemorrhagic fever in Iran. Transbound Emerg Dis. 2008;55:200-4.

14. Keshtkar-Jahromi M, Kuhn JH, Christova I, Bradfute SB, Jahrling PB, Bavari S. Crimean-Congo hemorrhagic fever: current and future prospects of vaccines and therapies. Antiviral Res. 2011;90:8592.

15. Keshtkar-Jahromi M, Sajadi MM, Ansari H, Mardani M, Holakouie-Naieni K. Crimean-Congo hemorrhagic fever in Iran. Antiviral Res. 2013;100:20-8.

16. Shepherd AJ, Swanepoel R, Leman PA. Antibody response in Crimean-Congo hemorrhagic fever. Rev Infect Dis. 1989;11:801-6.

17. Cruz DN, Ricci Z, Ronco C. Clinical review: RIFLE and AKIN--time for reappraisal. Crit Care. 2009;13(3):211. doi:10.1186/cc7759.

18. Sumer A. The evaluation of the patients who were admitted to the emergency department of Kaș State Hospital because of tick biting. Kafkas Üniv Vet Fak Derg 2010;16:49-53.

19. Bilgin G, Ataman Hatipoglu C, Altun S, Bulut C, Kinikli S, Demiröz AP. An investigation of pulmonary findings of Crimean-Congo haemorrhagic fever patients. Send to Turk J Med Sci. 2014;44:162-7.
20. Hasanoglu I, Guner R, Carhan A, Kocak Tufan Z, Yagci-Caglayik D, Guven T, et al. Crucial parameter of the outcome in Crimean Congo hemorrhagic fever: Viral load. J Clin Virol. 2016;75:42-6.

21. Inci A. The Prevalence of Crimean-Congo Haemorrhagic Fever and the Significance of Geographic, Climatic Features, and Tick Abundance, Klimik Derg. 2015;28: 68-71.

22. Durrani $A B$, Shaikh $M$, Khan Z. Congo crimean hemorrhagic Fever in balochistan. J Coll Physicians Surg Pak. 2007;17:543-5.

23. Cevik MA, Erbay A, Bodur H, Gülderen E, Baștuğ A, Kubar A, et al. Clinical and laboratory features of Crimean-Congo hemorrhagic fever: predictors of fatality. Int J Infect Dis. 2008; 12:374-9.

24. Yilmaz G, Koksal I, Topbas M, Yilmaz H, Aksoy F. The effectiveness of routine laboratory findings in determining disease severity in patients with Crimean-Congo hemorrhagic fever: severity prediction criteria. J Clin Virol. 2010;47:361-5.

25. Tasdelen Fisgin N, Tanyel E, Doganci L, Tulek. Risk factors for fatality in patients with Crimean-Congo haemorrhagic fever. Trop Doct. 2009;39:158-60.

26. Onguru $P$, Dagdas $S$, Bodur $H$, Yilmaz $M$, Akinci $E$, Eren S, et al. Coagulopathy parameters in patients with Crimean-Congo hemorrhagic fever and its relation with mortality. J Clin Lab Anal. 2010;24:163-6.

27. Hatipoglu CA, Bulut C, Yetkin MA, Ertem GT, Erdinc FS, Kilic EK, et al. Evaluation of clinical and laboratory predictors of fatality in patients with Crimean-Congo haemorrhagic fever in a tertiary care hospital in Turkey. Scand J Infect Dis 2010;42:516-1.

28. Kazancioglu S, Akinci E, Baștug A, Kayaaslan B, But $\mathrm{A}$, Aslaner $\mathrm{H}$, et al. Does the course of laboratory parameters help us to predict the outcome of CCHF? Turk J Med Sci. 2016;46:328-34. 